Yu. M. Brovender, Dr. Sc. (Histor.), Assoc. Prof., orcid.org/0000-0001-6372-0812, V. N. Okalelov, Dr. Sc. (Tech.), Prof., orcid.org/0000-0002-7844-5080
Volodymyr Dahl East Ukrainian National University, Severodonetsk, Ukraine, e-mail: brovender@ukr.net; okalelov@ukr.net

\title{
ON EXTRACTION OF ORE MINERALS OF THE DONETSK BASIN IN THE EARLY METAL AGE
}

Purpose. Comprehensive analysis of ancient mining monuments of the Paleometal era in the Donetsk basin associated with the extraction of metal ores; determination of the cultural and chronological affiliation of the Berezovskyi mine on the extraction of silver ores - a unique object of ancient mining in Eastern Europe.

Methodology. The work involved a set of methods: retrospective, historical and comparative, cartographic, statistical ones, method of analogies, method of typological and functional analysis. In addition, mineralogical methods were used to study sulfide ores (mineral diagnostics), the method of stratigraphic, mineralogical and petrographic analysis and a retrospective description of the mining technology development.

Findings. The results significantly expand the understanding of the resource base of the Donetsk basin exploited in the Bronze Age. The complex of ancient stone mining tools identified in one of the mine workings of the Berezovskyi silver-polymetallic deposit allows suggesting its development by the population of a catacomb cultural community during the Middle Bronze Age (XXVII-XX centuries BC). And this, thereby, makes productive time of the Donbass ore base more remote, known from the materials of the ancient mines of the Late Bronze Age (XVIIXIII centuries BC) in the copper ore zone of the Bakhmut depression of the Donets Basin almost by a thousand years.

Originality. For the first time in the territory of Eastern Ukraine an ancient silver ore mine was discovered. To date, their exploitation in antiquity, in contrast to polymetallic ores, was not even anticipated by researchers. The Caucasus was traditionally considered to be the main source of raw materials for the manufacture of silver products of by the population of the Eastern European steppe and forest-steppe in the Bronze Age. The study made it possible to expand not only the raw material base of the ancient Donbass population of the Bronze Age (XXX-XIII centuries BC), but also the chronological framework of its mining activities for the extraction of metal ores.

Practical value. The data obtained expands the understanding of the raw material base used by the ancient population of the Donetsk basin. In turn, this will contribute to the formation of a holistic view on the metal production of the ancient inhabitants in the Eastern European region, which may probably be applied in preparing special works on ancient history, including the history of mining, as well as related disciplines, in the systematization of funds and the designing the museum exhibits.

Keywords: Berezovskyi mine, Donetsk mining and melting center, Kartamysh archeological microdistrict, Nagolnyi ridge, silver-polymetallic ores, Early Metal Age

Introduction. Metal production in the EneolithicBronze Age (mid-VI - late II millennium BC) always attracted the attention of researchers in various regions of the world. In recent years, the problem of ancient metal production has been dynamically developed in Eastern Europe. This activity is to a certain extent due to the results of large-scale field archaeological work on ancient settlements in the area of the Kargaly copper deposit (South Ural) (1992-1999) and the Kartamysh copper ore occurrence in the Donbas (2001-2009). Their excavations yielded informative material of the Late Bronze Age (XVII-XIII cc. BC) to a greater extent associated with mining and mineral processing and, to a lesser extent, with metallurgy and metalworking. This enabled to get closer to solving the problem of the copper ore base of the ancient societies of the Eastern European steppe and the problem of organizing the mining industry in the $2^{\text {nd }}$ millennium BC.

The research interest in ancient usage of the polymetallic ores of the Nagolnyi Ridge of Donbass did not come round this issue. However, for a long time this possibility was only assumed in connection with the dis-

(C) Brovender Yu. M., Okalelov V. N., 2019 covery in these parts during geological exploration (Panasenko, 1936; Stepanov, 1977; Zhulid, 1985) of obvious artificial violations of geological strata, which created an idea of their ancient origin. Other data indicating the connection of these artificial violations in the zone of silver and polymetallic ores deposits was not known, and therefore, the age of the alleged ancient mine workings stayed open.

This circumstance dictated the need for a thorough survey of the territory in the zone of the above violations and carrying out some analytical study if relevant evidence was revealed.

The data currently available allow a comprehensive look at the problem of the mining activity (production) of metal ore mining by the ancient miners of the Early Metal Age in the territory of Donbass.

Analysis of the recent research and publications. In solving the problem of ancient metal production, an important place is occupied by mining and metallurgical complexes. At present, in various regions of the world, including Jordan [1], Laos [2], Chile [3], Egypt, Sudan [4], Greece [5], the research studies are carried out on ancient centers for the extraction of non-ferrous (gold, silver) metals. 
Active archaeological studies of mining and metallurgical monuments of the Late Bronze Age of Eastern Europe performed at the turn of the $\mathrm{XX}-\mathrm{XXI}$ centuries in the recent years were replaced by a period of in-depth scientific analysis and synthesis. We are talking about such complexes as Kargaly in the South Urals region (Chernykh, 2007) and Kartamysh in Donbass [6].

However, all East European mining monuments investigated by the excavations are associated exclusively with copper ores. The mines specializing in the extraction of silver ores were not known in these parts at all. The main source of raw materials for the production of silver jewelry in the Bronze Age traditionally considered the Caucasus.

The discovery of traces of ancient mining operations in the area of Berezovskyi silver-polymetallic deposit with a complex of stone mining tools suggests their functioning in the paleometal epoch.

The discovery of the ancient mine on Nagolnyi Ridge in the form of brief informational messages was mentioned in the materials of the X International Scientific Conference "Problems of History and Archeology" dedicated to the $125^{\text {th }}$ anniversary of Professor K. E. Grinevich (Kharkiv, 2016) [7], as well as the All-Russian Youth Scientific School "Geoarcheology and archaeological mineralogy" (Miass, 2018) [8]. However, to date there are no works in the literature that provide a comprehensive analysis of the mining activity in the era of early metal on the extraction of silver ores in the area. In addition, there are no works in which the corresponding graphic and illustrative material is reflected. These circumstances dictated the necessity to overcome the situation.

Topicality. The importance and extreme relevance of this issue are due, above all, to the fact that metal products obtained by performing the most complex technological operations are the most important source for studying the history of one of the leading industries in the production of pre-historic societies. However, if copper production in the Early Metal Age was already reflected in the scientific literature (Kargaly (Chernykh, 2007), Mikhailo-Ovsyanka (Matveyeva, Kolev, Korolev, 2004) and Kartamysh) [6], the production of precious metal products, including their raw materials base is a poorly developed problem.

Particularly relevant for Eastern European archeology is the problem of raw materials sources for the production of silver goods in the era of early and middle bronze (XXX-XXIII centuries BC), which featured the abundance of silver inventory in the burials.

Objectives of the article. The results of perennial archaeological excavations of mining and melting sites in the Donets Basin, as well as their scientific understanding, determined the purpose of this work. It consists in a comprehensive analysis of mining activities on the extraction of metal ores by ancient miners of the Donets Basin of the Paleometal Epoch, as well as the cultural affiliation and time of operation of the unique monument throughout the entire Eastern European region the Berezovskyi mine on the extraction of silver ores on Nagolnyi Ridge.
Methods. The work is based on the whole arsenal of methods, including: retrospective, historical and comparative, cartographic, and statistical ones, the method of analogies, the method of typological and functional analysis, as well as mineralogical methods for studying sulfide ores (diagnosis of minerals), the method of stratigraphic, mineralogy-petrographic analyses and retrospective description of technology development of mining.

Results. The Donetsk mining and metallurgical center played an important role in the development of the production activities of the population massifs in the Eastern European region of the early metal epoch. Unfortunately, not all experts in the field of ancient production recognize the scale and significance of this center. Some of them (N. V. Ryndina, 2002; V. S. Bochkarev, 2006; E. N. Chernykh, 2007) see the dependence of metal production in the Eneolithic - Bronze, at least in Left-Bank Ukraine, from Balkan, Caucasian or Volga-Ural raw materials sources.

Active field research at the turn of the past and present centuries, carried out within the Kartamysh ore occurrence zone - the richest place in the Bakhmut basin of the Donets Basin copper ore manifestations, contributed to the discovery of large-scale production facilities of the Bronze Age. Their research allowed opening the curtain of the problem associated with metal production, to a greater extent, the carriers of the log cultural tradition of the late Bronze Age (XVII-XIII centuries $\mathrm{BC})$. Among the investigated complexes there are mine workings of the quarry and underground types, an extensive production (technogenic) site where copper ore was prepared, and also two settlements with numerous finds of ancient metal production [6].

The total area of monuments of Kartamysh archeological microdistrict (KAM) investigated by the excavations has been $1290 \mathrm{~m}^{2}$. Considering the research degree performed by the overburden works of mining and metallurgical monuments in the Eastern European region, it is reasonable to consider the Kartamysh production microdistrict the most extensively excavated in Eastern Europe. KAM excavations and scientific understanding of its materials were carried out with the participation of specialists in the field of natural and technical sciences: geologists, geotechnologists, metallurgists and others. This permitted us to give a comprehensive description of the production process here in antiquity. Data were obtained on the technology of mining, preparation, and melting of ore. Using mineralogical and petrographic methods, stone tools used in the production process were investigated, most of which are not of local origin, but have analogues among raw materials mined in the Bronze Age on the territory of the Ukrainian shield [9, 10]. The latter fact testifies to the distant trade relations of the Kartamysh inhabitants.

The result of a comprehensive review of KAM monuments, as well as production facilities at other ore manifestations of the Donets Basin, previously identified and explored by S. I. Tatarinov [11] was the idea about the Donetsk Mining and Metallurgical Center (DMMC) as a complex Late Bronze Age monuments focused on 
large-scale mining of copper ore and its preparation and located in the area accessible for the development of ancient technologies of Bakhmut copper ore manifestations [6]. As a result, the idea of the genesis and deactivation date of the DGMC, as well as the cultural and chronological affiliation of this center, vague among researchers, was overcome by the concept of Yu. M. Brovender about the occurrence of DGMTs as a result of the progressive development of metal production in the Dnipro-Don region, whose beginning is not unreasonably associated with the Eneolithic era (mid- $6^{\text {th }}-4^{\text {th }}$ millennium BC) [6]. However, metal production in the era of early metal was not limited to the copper ore potential of the Bakhmut Basin. This idea has repeatedly appeared in the scientific literature, but until recently was of a hypothetical nature. The information from some authors about the traces of ancient ore developments in the Donbas, on whose territory ancient mountain tools were discovered, unfortunately, cannot be verified. So, in the western part of the Main Donetsk anticline, $4 \mathrm{~km}$ west of Nikitovka railway station there is located mercury deposit - cinnabar. The total area of the ore field does not exceed 6-7 $\mathrm{km}^{2}$. Cinnabar dominates in the mineral composition of the ore (mercury content reaches $0.36 \%$, sometimes rises to $2 \%$ ). Associated minerals are stibnite, pyrite, melanterite, iron hydrates, antimony ocher, arsenopyrite, epsomite (Turley, 1936). The data of mining engineer A. V. Minenkov on the traces of ancient ore explorations recorded at the Nikitovsky deposit of the Donbas is worth attention (R. M. Bagatayev, V. M. Rogova, 2011). Unfortunately, the colossal scope of mining operations in the previous century completely destroyed all traces indicating the possibility of their operation in antiquity.
Due to new discoveries the polymetallic ores deposits of the Donetsk basin are increasingly attracting the attention of specialists. Polymetallic ores lie among sandstones and shale of coal deposits in the region of the Main Donetsk anticline, mainly in the vicinity of the Nagolnaya Tarasovka in Dolzhanskaya area, Luhansk region (Fig. 1).

Deposits of polymetallic ores are located on the rearing low ridges of the Nagolnyi Ridge, which is a sub-latitudinal eastern extremity of the Donetsk Ridge between the Kamenka river (the Seversky Donets basin) and the upper reaches of the Nagolnaya and Mius rivers.

On Nagolnyi i ridge known lead-zinc (Esaulovske, Nagolno-Tarasivske, Central Nagolchanske, LowerNagolchanske, South Esaulovske, Hrekivske, Diakovo), silver-base metal (Zhuravske, Berezovske, Semenov Hillock, South Vyshnevetske), gold-polimetallic (Bobrikovsky, Ostrobugorske) deposits and occurrences (Stepanov, 1977; Zhulid, 1985). These objects are of vein type and are mainly presented by steeply dipping veins of small and medium depths. The main ore minerals of the Nagolno-Tarasivske field are galena $\mathrm{PbS}$, sphalerite $\mathrm{ZnS}$, pyrite $\mathrm{FeS}_{2}$, arsenopyrite FeAsS, tetrahedrite $(\mathrm{Cu}, \mathrm{Ag})_{10}\left(\mathrm{Zn}, \mathrm{Fe}_{2} \mathrm{Sb}_{4} \mathrm{~S}_{13}\right.$. On the site of $\mathrm{Se}-$ menov mound, the finds of silver nuggets are known. At the Zhuravske deposit, the bulk of silver is localized in galena (up to the first kilogram per ton) and in tetrahedrite (up to $10 \mathrm{~kg} / \mathrm{t}$ ). The main copper minerals are tetrahedrite, $\mathrm{Cu}_{5} \mathrm{FeS}_{4}$ bournonite and $\mathrm{CuFeS}_{2}$ chalcopyrite; lead - galena and tetrahedrite; zinc - sphalerite; arsenic - arsenopyrite. The latter is the most common ore mineral of the Nagolno-Tarasivske deposit (Gursky, Yesipchuk, Kalinin, Kulish and others, 2005).

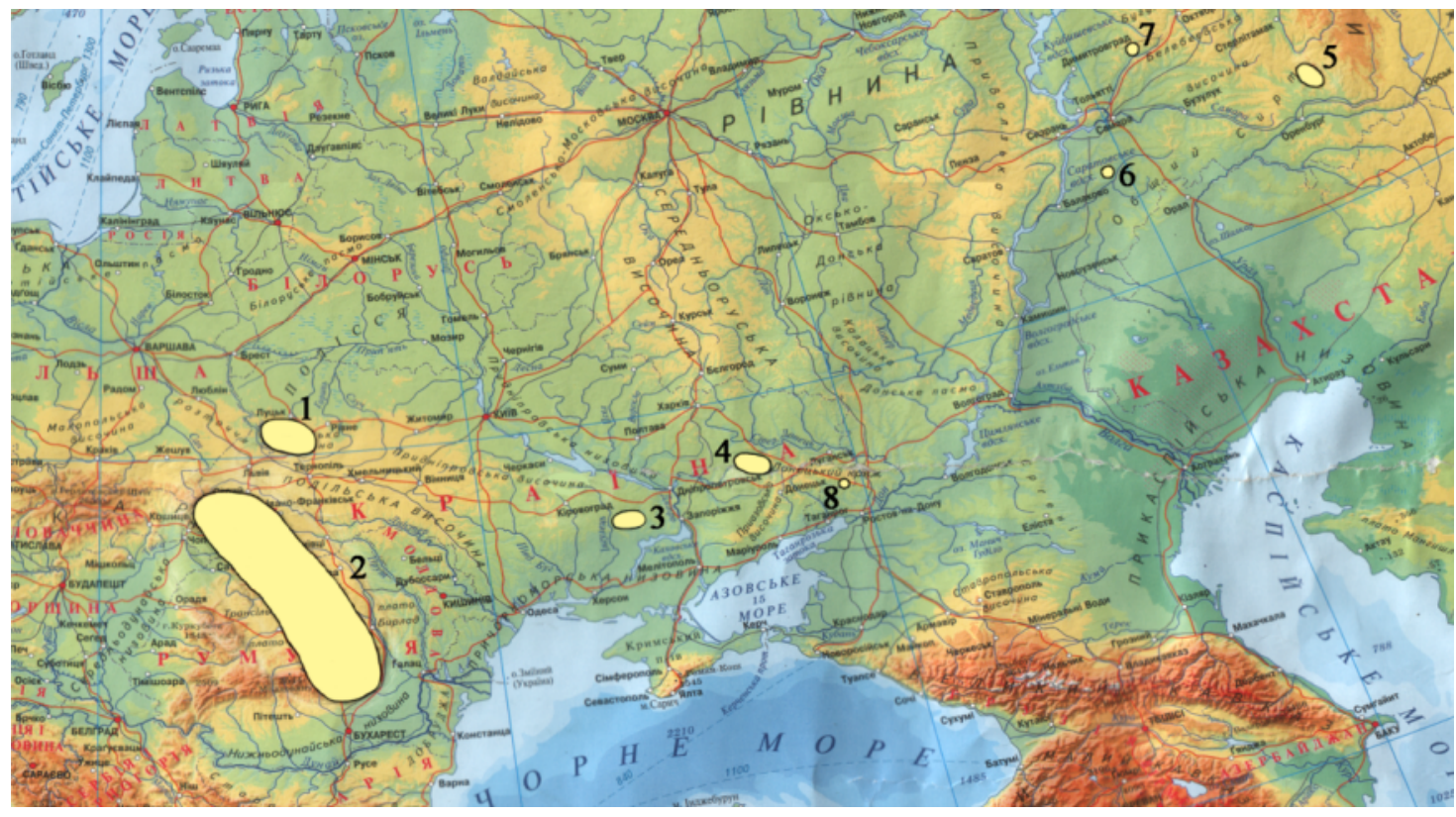

Fig. 1. Areas of copper and polymetallic ore occurrences on the territory of Eastern Europe, developed in the EneolithicBronze Age:

1 - Volyn ore occurrences; 2 - occurrences of the Carpathians; 3 - occurrences of the Kryvyi Rih basin; 4 -ore occurrences of the Donets Basin; 5 - Kargaly ore field; 6-occurrence near Mykhailo-Ovsianka; 7 - occurrences on the right bank of the Sok river; 8 - Polymetallic ores of the Nagolnyi ridge 
As a result of complex geological and archaeological field research on the territory of the Nagolnyi i ridge, the authors of this work together with the geologist Yu. P.Shubin nearwith Nagolno-Tarasivka examined traces of ancient mining operations. They were visually recorded on the Berezovskyi and Zhuravsky silver-polymetallic deposits.

Earlier, these mines were examined by I. A. Pislariy (1979). The information from geologists about the exploration ditches and pit holes of underground mine workings that they traced in antiquity to the vein bodies of silver-polymetallic ores of Berezovskyi and Zhuravskyi deposits (Panasenko, 1936; Stepanov, 1977; Zhulid, 1985) were not confirmed by archaeological material. Evidence of their exploitation in the Early Metal Age I. A. Pislariy during his short survey of mine workings could not be identified. Only the location of the barrow on the rock dump of one of the mines, as the researcher said, to a certain extent testified to the possible excavation of these ores in antiquity (Pyslariy, 1979).

Since systematic archaeological studies of these mines, as well as the territory directly adjacent to them, were not performed, their cultural and chronological definition remained open. However, a whole series of stone mining tools, found by the authors on the surface of the mine workings in the central part of the Berezovskyi mine, suggests the extraction of silver-polymetallic ores in the early metal epoch.

Berezovskyi mine is located on the hilltop of the copper ridge, stretching along the north-west - southeast line and going about 500 meters. It is a chain of funnel-shaped dish - mine workings, located apart ( 2 objects), or creating a complex. In total, there are three such complexes. Each of them includes from two, in the central part of the mine, to nine workings in the north-western part of it. In a plan most of the workings have a rounded shape and only a few are of an oval shape. Their diameter varies from 10 to $50 \mathrm{~m}$. The depth of dishes is from 1 to $3.5 \mathrm{~m}$. Complexes and single-lying mine workings surround barely visible traces of rock dumps. The surface of the dishes and heaps is turfed. Fragments of different-grained sandstones, quartz and ankerite veins were found in the dumps.

In the plan the workings are located at random. Separation pillars do not differ with their systemic location as well. According to geological observations, the latter is due to the morphology of ore bodies and the uneven distribution of ores in them (Zhulid, 1985). Pillars, apparently, can be areas of oreless or impoverished ore rocks, and quite possibly, they were left for the case when geological conditions get harder.

According to external signs, the Berezovskyi mine is very close to the Pilipchatino-I mine of the DGMTs at the Kisly Hillock copper mine in the Bakhmut district of the Donetsk region. There are also at least seven underground mine workings along the ore ridge.

In the structure and characteristics of rocks destroyed by the workings craters of Berezovskyi mine, geologist V.A. Juliet (1985) noted the following specific features. The craters are made of angular fragments of similar size and homogeneous rocks. Elements of the initial strata of rocks can be traced in the location of fragments for several meters, but in a distorted destroyed occurrence. The next feature is the absence of gangue material, and humus as well. All this, according to the researcher, indicates that the observed debris is not the result of dumping the dumps, but the result of rock strata crushing above the undermined space. Fragments of rocks are partly in contact with each other, partly separated by thin hollow slots. When opening the craters of mine workings with the geological search trenches, it was possible to notice their moisture saturation. Collapse boundaries are sharp. In the vicinity of the collapse zone, fragile rocks are intensely broken by concentric cracks, and for more ductile differences, the layers turn toward collapse.

The mineralization of the Berezovskyi area is veinveinlet, galena-sphalerite in composition. However, rich silver mineralization has been discovered here. Silver is found in a dispersed form in the main sulfide minerals, especially in galena.

A series of stone mining tools in the form of whole products and fragments was found at the bottom and on the waste dump of a mine working located in the center of the Berezovskyi mine. In total, the collection includes at least 13 products (Fig. 2).

The tools are made of dense gray quartzite by upholstery and picket technique. They are represented by hoes ( 1 copy), pickles (3 copies), hammers (4 copies), as well as tools that combine the functions of a pick and hammer (3 copies).

The hoes had a rectangular shape and a wide wedgelike finish in the profile (Fig. 2, $m$ ). This group of tools was used in the overburden operations in the mine. Hacks differed by elongated proportions and a sharp end of the working edge (Fig. 2, $l, n, p)$. These tools were used for penetration (breaking) into dense rocky ground.

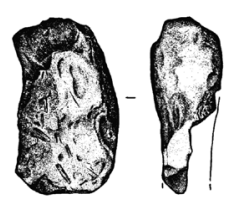

a

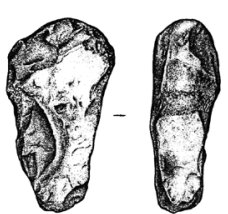

d

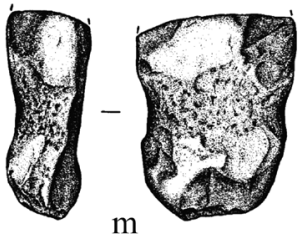

$\mathrm{m}$
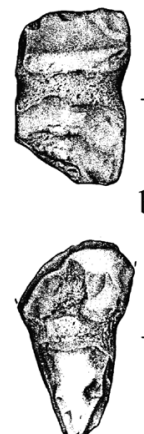

e

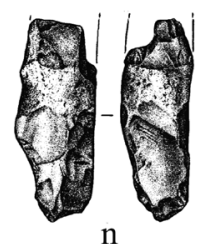

1

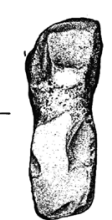

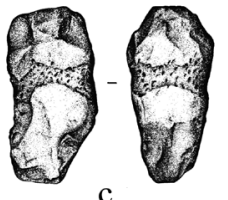

c

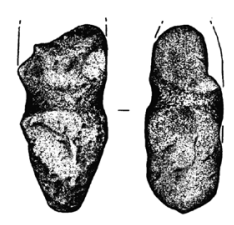

1

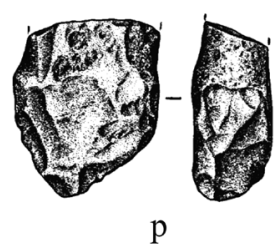

$\mathrm{p}$
Fig. 2. Berezovskyi Mine. Mining cycle tools:

$a-a$ billet of a mining tool (hammer); $b, c$ - hammers; $d$, $e-$ products combining the functions of a pick and a hammer; l, $n, p-$ a pick; $m$ - a hoe 
Hammers are represented by massive trapezoid-shaped tools (Fig. 2, b, c). They were used both in the process of mining and in ore preparation. A rather interesting group of mountain tools are products combining the functions of a hack and a hammer (Fig. 2, $d, e$ ).

Among the collection of findings there are preforms of mining tools (Fig. 2, a). This fact suggests their manufacture directly at the mine workings. All tool groups have a gutter for fastening straps, as well as a corresponding flattened surface for the wooden handle to be rest on.

Comparing mine tools from Berezovskyi mine and the mines of the DMMC the KAM tools of the late Bronze Age displays the most representative collection and allows us to draw some conclusions.

With the relatively typological proximity of mining instruments of these complexes, which is a common Eurasian trend, differences can be traced. The absence of polyfunctional tools cannot help being noticed within the monuments of the Donetsk center combining the functions of a pickle and a hammer (Zagorodnyaya, 2014). Berezovskyi tools have elongated proportions in contrast to the rounded/subsquare proportions of the mining tools of the DMMC. The edges of the DMMC tools are smoothly curved, which is most clearly seen for the hammer group. The tools of Berezovskyi mine have practically sharp corners. The mining tools of the DMMC are less massive than the tools of Berezovskyi mine. Without dating material on the surveyed archaeological complex of the Nagolnyi Ridge, the traceable differences suggest cultural and chronological heterogeneity of DMMC mining tools of the late Bronze Age and Berezovskyi mine.

Even without diagnostic sources in cultural and chronological terms at Berezovskyi mine, there is a prospect of studying an ancient production within the Donetsk basin specialized in the extraction of silverpolymetallic ores, which was carried out by the miners of the Early - Middle Bronze (XXX-XX centuries BC). It is observed in a broad analysis of the source base, far beyond the boundaries of the Nagolnyi Ridge.

An important source in solving the problem of the exploitation time of silver-polymetallic ores of the Nagolnyi Ridge are metal products originating from funerary complexes.

The total number of Eneolithic burials of the Bronze Age analyzed in the Dnipro-Don region is 9238 units. 904 burials were examined in detail, whose inventory contained metal items (2678 copies). Within them the number of analyzed burials with metal inventory was 758 units.

The total number of burials of the Eneolithic era (VIV millennium BC) taken into account in the sample is 385, and the Pit community of the Early Bronze Age (XXX-XXIII centuries BC) - 1802; the Catacomb community of the Middle Bronze Age (XXVII-XX centuries BC) - 3425; Babinskyi community of the transitional era from the Middle to the Late Bronze Age (XXII-XVIII centuries BC) - 597; Late Bronze Srubna community (XVII-XIII century BC) - 3029. Within them the number of metal-containing burials is as fol- lows: Aeneolithic - 38; Pit community - 119; Catacomb community - 440; Babinskiy community - 40; Srubnyy community -121 .

Practically all the decorations made of metal in the Eneolithic burials of the Dnipro-Don region are copper (244 copies/94.2\%). Only 14 copies $/ 5.4 \%$ of products are made of silver and 1 copy/ $0.4 \%$ of antimony. It is important to note that all silver and antimony jewelry in this sample comes exclusively from the Rostov region of the Russian Federation, which is the southeast area of the Dnipro-Don region, the closest area to the orebearing Caucasus.

For the early Bronze Age, the progressive development of not only copper processing and its alloy in the form of arsenic bronze, but also metals such as lead and silver, is characteristic. Here, the genetic connection of galena, like the lead ore mineral, with silver ores is noteworthy. Among the total number of metal ornaments of the pit community of the Dnipro-Don region (123 copies), products made of lead make up $3.2 \%$, and those of silver make up $22 \%$. A regional comparison of the burials of the pit cultural community (PCC), whose inventory contained silver products, allows us to distinguish the eastern area of the Dnipro-Don region (the Don river basin), both by the number of burials and by the number of silver ornaments in them. So, within the investigated region according to the number of such PCC burials within the investigated region, Luhansk region $(62.5 \%)$ stands out in the eastern range and Kherson region $(60 \%)$ in the western area of the Dnipro-Don region (the Dnipro river basin). According to the number of silver products in PCC burials, the Rostov region of the Russian Federation (34.3\%) is in the eastern range and the Kherson region $(12.5 \%)$ in the western area of the investigated region. Attention is drawn to the fact that in the eastern part of the Dnipro-Don interfluve the number of silver jewelry in PCC burials, investigated in the Rostov region of the Russian Federation, is only $6.5 \%$ more than those in PCC burials, investigated in the Luhansk region.

Frequently found findings of silver products in the Late Pit and Early Catacomb burials of different regions attracted the attention of specialists (Klochko, 1994, Bratchenko, 2001, Chernykh, 2002, Ivanova, 2007). Stating a high percentage of silver jewelry in the Northeast Azov, Lower Don and other areas, Bratchenko S.N. even considered jewelry development possible at the end of the Early - the beginning of Middle Bronze called silver and bronze.

Metal ornaments of the Catacomb cultural community (CCC) differ from the PCC jewelry by an incomparably greater typological diversity, as well as by the wider use of various metals (silver $-4.7 \%$, lead $-0.6 \%$, gold $-0.1 \%$, antimony $-1 \%$, iron $-0.1 \%$ ).

The largest number of CCC burials of the DniproDon region with silver implements can be traced in the Rostov region (21 copies/5.2\%). Slightly inferior to this indicator are the PCC burials of the Luhansk region (37 copies/4.7\%).

A somewhat different ratio is observed when comparing the amount of metal products in the CCC buri- 
als. In the Dnipro-Don region the largest amount of silver jewelry in the PCC burials was found in the Luhansk region (37 copies/6.4\%). Somewhat less they were in the Rostov region of the Russian Federation (21 copies/6.2\%)

Significant in solving the problem we are studying is the resultant cumulative statistics by E.I. Gak (2005) on silver jewelry in the CCC burials of the steppe Ciscaucasia, the Lower Don and the Seversky Donets. In accordance with his statistical sample (321 analysis), it is $3.8 \%$.

The assumption about the possible development of Nagolnyi Ridge silver ores by the CCC population becomes even more probable if we take into account the information on a number of CCC household, monuments abnormally high for the Severskodonetsky Right Bank area, on the Nagolnyi Ridge mentioned by S. N. Sanzharov (2010).

The general trend, both in the number of burials and in the number of silver products in the burials of the Catacomb community in the region under consideration, is their decrease to the west of the southeastern part of the eastern range of the studied region (Zaporizhzhya region -3 copies/2.7 \%; Dnipropetrovsk region -1 copy $/ 1.8 \%$ ).

The entire small collection of metal products of Babinskyi cultural community is made of bronze/copper.

In the Late Bronze Age, as in previous periods, copper was the basic material (151 copies/96.8 \%) in the metal production of the population of the Dnipro-Don region. The use of other metals, judging by the metal products of the graves of Srubna community, was not noticeably developed in the Late Bronze Age (gold (2 copies/1.3\%), antimony (2 copies/1.3\%), iron (1 copy/0.6\%).

Thus, the results of a retrospective analysis of mapping data and statistics of the Eneolithic - Bronze Age Dnipropetrovsk region's burial complexes with metal, including silver products display the possibility of producing silver ores of the Nagolnyi Ridge by the carriers of the Middle Bronze Age catacomb culture. At the same time, we do not exclude the beginning of their development in the late-pit time, matching to the early Bronze Age. However, for the final resolution of this issue large-scale field studies are required.

Conclusions. The currently available source base suggests that the ancient population of the Donets Basin in the Early Metal age had a dynamically developing mining industry specialized in metal ores.

The underestimation of the mining production scale and the role of the ancient population of the Donets Basin of the Bronze Age in the development of the metal industry in the Eastern European region recedes into the past. The Donetsk Mining and Metallurgical Center (XVII-XIII BC), which originated in the Late Bronze Age on the basis of copper ores of the Bakhmut Basin, was both a geographical and raw material center of the Dnipro-Don region, providing prepared copper ore (copper ore concentrate), first of all for specialized workshops.
According to the results of the investigation, Donetsk copper ores were not the only raw materials developed by ancient miners. The discovery of an ancient mine with a complex of stone mining tools at the Berezovske deposit of silver-polymetallic ores of the Nagolnyi Ridge let us confidently announce about silver ores production in these parts in the Early Metal age. There is a reason to assume their development in the Middle Bronze Age by the carriers of a catacomb cultural community. Further field research on Nagolnyi Ridge will finally resolve this issue.

\section{References.}

1. Gratten, J.P., Gilberson, D.D., Waller, J.H. and Adams, R. B., 2014. The geoarchaeology of "waste heaps" from the ancient mining and beneficiation of copper-rich ores in the Wadi Khalid in southern Jordan. Journal of Archaeological Science, 46(1), pp. 428-433.

2. Tucci, A., Sayavongkhamdy, T., Chang, N. and Souksavatdy, V., 2014. Ancient Copper Mining in Laos: Heterarchies, Incipient States or Post-State Anarchists?, 2014. Journal of Anthropology and Archaeology [online], 2(2), pp. 1-15. Available at: <https://www. researchgate.net/publication/272373694_Ancient_ Copper_Mining_in_Laos_Heterarchies_Incipient_ States_or_Post-State_Anarchists> [Accessed 17 April 2018].

3. Zori, C. and Tropper, P., 2013. Silver lining: evidence for Inka silver refining in northern Chile. Journal of Archaeological Science, 40, pp. 3282-3292.

4. Klemm, R. and Klemm, D., 2013. Gold and Gold Mining in Ancient Egypt and Nubia. Geoarcheology of the Ancient Gold Mining Sites in the Egyptian and Sudanese Eastern Deserts. Springer-Verlag Berlin Heidenberg, 648 p. [online]. Available at: <https://books. google.com.ua/books?id=ky8bVJ_fYEAC\&printsec $=$ frontcover $\& h \mathrm{l}=\mathrm{ru} \& \mathrm{sou} r \mathrm{ce}=\mathrm{gbs} \mathrm{ge}_{-}$ summary_r\&cad $=0 \# \mathrm{v}=$ onepage $\& \mathrm{q} \& \mathrm{f}=$ false $>[\bar{A}$ ccessed 7 March 2018].

5. Paralas, G., 2016. Ancient Greek silver mine discovered on Aegean Shore [online]. Available at: <http://www.newhistorian.com/ancient-greek-silver-mine-discoveredon-aegean-shore/ 5955/> [Accessed 28 February 2017]. 6. Brovender, Yu. M., 2017. On the issue of metal production development in Dnepro-Donetsk region in the Eneolithic - Bronze Age. Herald of V.Dahl East-Ukrainian National University, 11(241), pp. 21-26.

7. Brovender, Yu. M., 2016. On the issue of Donbass mining and metallurgical region in the Bronze Age. In: Problems of History and Archeology: Materials of the $X$ International scientific conference dedicated to 125 anniversary of prof. K.E. Grinevich, Kharkiv, 2016 [online], pp. 11-12. Available at: <https://khiao.wordpress. com/2016/10/25/news-36/> [Accessed 11 February 2018].

8. Shubin, Yu. P., 2018. Some aspects of geoarcheological investigations of the metal production objects in the Bronze age (by example of Donbass). In: Geoarcheology and archeological mineralogy - 1018. Materials of the V All-Russia Youth scientific school [pdf], pp. 149151. Available at: <http://baseserv.ilmeny.ac.ru/files/ 
BIBLIO/BOOKS/22148.pdf> [Accessed 5 October 2018].

9. Nikitenko, I. S. and Lysenko, S. D., 2014. Results of the mineralogical and petrographic analysis of stone goods from the burial ground Malopolovetskoye-3 and the settlement Malopolovetskoye-2A (Kiev Region). Stratum Plus, 2, pp. 333-345.

10. Nikitenko, I. S., Starik, O.V., Kutsevol, M.L. and Shevchenko, S. V., 2018. Petrographic research on stone tools from the megalithic cult site of Tokivske-1, Naukovyi Visnyk Natsionalnoho Hirnychoho Universytetu, 4, pp. 5-12. DOI: 10.29202/nvngu/2018-4/1.

11. Tatarinov, S. J., 2018. Ancient miners and metallurgists of Eastern Ukraine. Kharkov: Express-book.

\section{Про видобуток рудних корисних копалин Донецького басейну в епоху раннього металу}

\section{Ю. М. Бровендер, В. М. Окалєлов}

Східноукраїнський національний університет імені Володимира Даля, м. Сєвєродонецьк, Україна, e-mail: brovender@ukr.net; okalelov@ukr.net

Мета. Комплексний аналіз пам'яток давнього гірництва доби палеометалу на території Донецького басейну, пов'язаних із видобутком металевих руд; визначення культурної та хронологічної належності Березовської копальні 3 видобутку срібних руд - унікального об'єкту давнього гірництва на території Східної Європи.

Методика. У роботі задіяний комплекс методів: ретроспективний, історико-порівняльний, формально-типологічний, функціонально-типологічний, картографічний, статистичний, аналогій. В арсеналі дослідження використані мінералогічні методи дослідження сульфідних руд (діагностика мінералів), метод стратиграфічного аналізу, мінерально-петрографічний метод, а також метод ретроспективного опису розвитку технології гірничої справи.

Результати. Отримані в результаті дослідження матеріали, а також на підставі їх аналізу данні істотно розширюють уяву про сировинну базу Донецького басейну, що експлуатувалася за доби бронзи. Комлекс давніх кам'яних гірничих знарядь, виявлений в одній із давніх гірничих виробок Березовського срібно-поліметалевого родовища дозволяє припускати його розробку населенням катакомбної культурної спільноти в епоху середньої бронзи (XXVII-XX ст. до н.е.). А це, у свою чергу, робить ще давнішим час експлуатації рудної бази Донбасу, відомої за матеріалами давніх мідних копалень пізньобронзового віку (XVIIXIII ст. до н.е.), у зоні мідних рудопроявів Бахмутської улоговини Донецького басейну майже на тисячу років.

Наукова новизна. Уперше на території Східної України виявлена давня копальня з видобутку срібних руд. До теперішнього часу їх експлуатація на
Нагольному кряжі в давнину, на відміну від поліметалевих руд, дослідниками навіть не передбачалася. Основним сировинним джерелом для срібних виробів населенням східноєвропейського степу й лісостепу традиційно вважався Кавказ. Проведене дослідження дозволяє розширити не тільки сировинну базу давнього населення Донбасу бронзової доби (XXX-XIII ст. до н.е.), але й хронологічні межі його гірничодобувної діяльності з видобутку металевих руд.

Практична значимість. Отримані дані розширюють уяву про сировинну базу, що використовувалася давнім населенням Донбасу, як і Східної Європи, у цілому, у металовиробничій діяльності, що може бути використано при підготовці узагальнюючих робіт з археології та давньої історії гірництва, при створенні музейних експозицій з краєзнавства, а також історії металовиробництва давнього населення України.

Ключові слова. Березовська копальня, Донецький гірничо-металургійний центр, Картамиський археологічний мікрорайон, Нагольний кряж, срібно-поліметалеві руди, доба палеометалу

\section{О добыче рудных полезных ископаемых Донецкого бассейна в эпоху раннего метала}

\section{Ю. М. Бровендер, В. Н. Окалелов}

Восточноукраинский национальный университет имени Владимира Даля, г. Северодонецк, Украина, e-mail: brovender@ukr.net; okalelov@ukr.net

Цель. Комплексный анализ древних памятников горного дела эпохи палеометалла на территории Донецкого бассейна, связанных с добычей металлических руд; определение культурной и хронологической принадлежности Березовского рудника по добыче серебряных руд - уникального объекта древнего горного дела на территории Восточной Европы.

Методика. В работе задействован комплекс методов: ретроспективный, историко-сравнительный, формально-типологический, функционально-типологический, картографический, статистический, аналогий. В арсенале исследования использованы минералогические методы исследования сульфидных руд (диагностика минералов), метод стратиграфического анализа, минералого-петрографический метод, а также метод ретроспективного описания развития технологии горного дела.

Результаты. Полученные в результате исследования материалы, а также на основе их анализа данные существенно расширяют представление о сырьевой базе Донецкого бассейна, эксплуатируемой в эпоху бронзы. Комплекс древних каменных горных орудий, выявленный в одной из горных выработок Березовского серебряно-полиметаллического месторождения, позволяет предполагать его разработку населением катакомбной культурной общности в эпоху средней бронзы (XXVII-XX вв. 
до н.э.). А это, тем самым, делает более ранним время эксплуатации рудной базы Донбасса, известной по материалам древних рудников позднебронзового века (XVII-XIII вв. до н. э.) в зоне медныХ рудопроявлений Бахмутской котловины Донецкого бассейна почти на тысячу лет.

Научная новизна. Впервые на территории Восточной Украины выявлен древний рудник по добыче серебряных руд. До настоящего времени их эксплуатация в древности, в отличие от полиметаллических руд, исследователями даже не предполагалась. Основным сырьевым источником для изготовления серебряных изделий населением восточноевропейской степи и лесостепи в эпоху бронзы традиционно считался Кавказ. Проведенное исследование позволяет расширить не только сырьевую базу древнего населения Донбасса эпохи бронзы (XXX-XIII вв. до н.э.), но и хронологические рамки его горнодобывающей деятельности по добыче металлических руд.
Практическая значимость. Полученные данные расширяют представление о сырьевой базе, используемой древним населением Донецкого бассейна. В свою очередь, это будет способствовать формированию целостного представления о металлопроизводстве древнего населения восточноевропейской степи и лесостепи, что может найти применение при подготовке специальных обобщающих работ по археологии, истории горного дела, а также смежных дисциплин, при систематизации фондов и создании музейных экспозиций.

Ключевые слова: Березовский рудник, Донеикий горно-металлургический центр, Картамышский археологический микрорайон, Нагольный кряж, серебряно-полиметаллические руды, эпоха раннего металла

Рекомендовано до публікації докт. техн. наук Г. І. Гайком. Дата надходження рукопису 19.01.18. 